\title{
施設スイカ畑の連輪作におけるサッマイモネコブセンチュウの発生消長
}

\author{
古賀 成司・古閉 孝彦（熊本県農業試験場園芸支場）
}

\begin{abstract}
Effects of cropping systems on population densities of the root-knot nematode (Meloidogyne incognita) in vegetable gardening under vinyl greenhouses. Seiji KoGA and Takahiko KogA (Horticultural Branch, Kumamoto Agricultural Experiment Station, Kikuchi-gun, Kumamoto 861-11)
\end{abstract}

施設野菜作地带では単一作物の連作による滈度な土地 利用が行われている。これは産地として必然的な結果で あり，また有利な経営方式と思われるが，一方では連作 に起因する各種生青障害の発生を招き易い結果となって いる。本県のスイカ産地, 特に大型八ウス栽培地帯にお いては, スイ力の生育障害として収穫前うよそ10日ない し20日の間に寻に萎调する，いわ妕る急性萎调症が大き な問題となっている。発生原因については種々諭議され てはいるが，いまだ不明な点が多い。

筆者らはこれまでの調査で，本症発生のスイカの根が， 線虫笴生によって異常なゴールを形成し，褐変あるいは 窝敗している場合の多いことから，線虫の関与を推定し た。そこで, 急性萎调症解明の一環として, 本症発生に 関与する線虫の役割とその程度を明らかにし，また線虫 の有効な生態的防除手段を探索するため, 各種作物の輪 作試験を行い，二：三の知見を得たので報告する。

報告に先だち, 試験当初から種々御指導を賜った熊本 紧農産普及課小林研三課長, 農事試験場後藤炤虫害第 2 研究室長, ならびに貴重な御助言と校阅を賜った九州農 業試験場大島康臣線虫研究室長, 調查に御協力いただい た熊本県農試病虫部中山武則主任研究員, 線虫の同定を 心よくしていただいた佐賀大学農学部近藤栄造氏，これ らの方々に謝意を表する。

\section{試駺方 法}

1976年, 熊本県農娬園芸支場連棟ビニールハウス内に 無底のブロック枠を設置し，1977年から1979年まで連・ 輪作倵験を行った。作付方法の概略を第 1 表に, 連・輸
作体系は第 2 表に示した。すなわち，ここで設定した体 系はスイカ産地の代表的作付体系であるスイカーキュウ リのウり類連作と，その作付前土壌消毒区，スイ力連作 区及びスイカーレタスの野菜類連作区であり，これに対 し基幹作スイカにラッカセイ，トウモロコシを導入した 輪作区と休閑区を設计た。サッマイモネコブセンチュウ (Meloidogyne incognita) の生息する黑色火山灰土壤 （CL）を供武し，規模は1区 $4 \mathrm{~m}^{2} ， 2$ 連制とした。供試 作物の品種は本県の主要截培品種を供試し, 耕種方法は 県耕種基準に準じて栽培管理を行った。なおスイカは全 てユウガオ台接木とした。試験ほ場の管理にあたっては 栽培管理作業等に上る隣接区相互の污染防止に極力努め た。線虫密度調查は赫培時期の前後，1区4力所で深さ 5〜15 cmの耕土を採土した後，ベルマン法によって11月 $\sim 4$ 月は $28^{\circ} \mathrm{C}$ ，この時期以外は室温，48時間で線虫を分 離し計数した。

\section{結果及び考察}

1. サッマイモネコブセンチュウの発生消長

各作物別にサッマイモネコブセンチュウの寄生, 增殖 を検討した結果スイカ，キュウリ，レタス及びトウモロ コシ栽培による線虫密度增加が著しく, 特にキュウリ， トゥモロコシで顕著に認められた(第 2 表)。一方ラッカ セイ仅び休䦥では線虫密度は減少した。作付体系別発生 消長ではスイカ一キュウリ，スイカースイカ，スイカー レタス及びスイカートウもロコシ体系は本線虫の密度增 加を助長しているとみてよい。またスイカーキュウリ体 系で作付前土譻消毒を実施した場合に扔いても低密度に

第 1 表 倠: 付 ji 洋

\begin{tabular}{|c|c|c|c|c|c|}
\hline \multicolumn{2}{|c|}{ 1977年 } & \multicolumn{2}{|c|}{ 1978年 } & \multicolumn{2}{|c|}{ 1979年 } \\
\hline $\begin{array}{c}7 \text { 月下旬 } \\
-9 \text { 月上昜 }\end{array}$ & $\begin{array}{c}9 \text { 月中旬 } \\
\sim 11 \text { 月下的 }\end{array}$ & $\begin{array}{c}3 \text { 月下旬 } \\
-6 \text { 月上旬 }\end{array}$ & $\begin{array}{l}8 \text { 月下旬 } \\
-11 \text { 月下们 }\end{array}$ & $\begin{array}{c}4 \text { 月下旬 } \\
-8 \text { 月下的 }\end{array}$ & $\begin{array}{c}9 \text { 月中旬 } \\
-12 \text { 月上间 }\end{array}$ \\
\hline $\begin{array}{c}\text { ス } 九 ~ \\
\text { (均一栈培) }\end{array}$ & $\begin{array}{l}\text { キュウリ,レタス, } \\
\text { ラッカセイ、トウ } \\
\text { ウモロコシ及U゙ } \\
\text { 休闌 }\end{array}$ & ス化力 & $\begin{array}{l}\text { キュウリ, スイカ, } \\
\text { レタス, ラッカ } \\
\text { セイ、トウモロ } \\
\text { コシ及U゙休閑 }\end{array}$ & スイカ & $\begin{array}{l}\text { キュウリ、スイカ, } \\
\text { レタス.ラッカ } \\
\text { セイ、トウモロ } \\
\text { コシ及U゙休䦥 }\end{array}$ \\
\hline
\end{tabular}


第 2 表施設野深烟の遇・輪作とネコブセンチュウの発生消艮

\begin{tabular}{|c|c|c|c|c|c|c|c|c|c|c|c|c|}
\hline \multicolumn{5}{|c|}{ 1977年 } & \multicolumn{4}{|c|}{ 1978年 } & \multicolumn{4}{|c|}{ 1979年 } \\
\hline 淎 & 作 & 虫 数 ${ }^{\mathrm{a}}$ & 夏秋作 & $\begin{array}{l}\text { 虫 数 }{ }^{\mathrm{a}} \\
\left(1 \mathrm{1} 12 \mathrm{~A}^{2}\right)\end{array}$ & 秦 作 & $\begin{array}{l}\text { 虫 数 } \\
(6 \mathrm{H} 20 \mathrm{H}\}\end{array}$ & 夏秋作 & 虫数 ${ }^{\mathrm{a}}$ & 秦 作 & $\begin{array}{l}\text { 虫 数 } \\
(8 \mathrm{H} 28 \mathrm{H})\end{array}$ & 夏秋作 & $\begin{array}{l}\text { 虫数b } \\
(12) 120 \text { 日) }\end{array}$ \\
\hline & 及 & 15 & $\neq$ & 332 & z & 358 & $\neq$ & 247 & ス & 238 & $\neq d$ & 102 \\
\hline & ス & 1 & 休 & 0 & T2 ᄌ & 2 & $\neq$ & 234 & ス & 293 & $\neq^{d}$ & 45 \\
\hline & ス & 6 & $\mathrm{~T} 1 \neq$ & 30 & $\mathrm{~T} 2 \mathrm{X}$ & 280 & $\mathrm{~T} 3 \neq$ & 164 & T4 ス & 8 & $\mathrm{~T} 5 \neq$ & 107 \\
\hline & 又 & 5 & $\neq$ & 540 & ス & 85 & xc & 8 & x & 353 & $x^{\prime \prime}$ & 253 \\
\hline & z & 5 & 休 & 1 & x & 3 & $x^{6}$ & 2 & X & 590 & $x^{\prime \prime}$ & 242 \\
\hline & x & 22 & L & 13 & x & 4 & v & 140 & x & 970 & $v$ & 486 \\
\hline & ス & 43 & $\overline{7}$ & 4 & x & 16 & $\Rightarrow$ & 1 & ス & 171 & 卜 & 618 \\
\hline & 又 & 6 & ラ & 1 & x & 28 & $r$ & 399 & x & 283 & $\overline{7}$ & 24 \\
\hline & 久. & 16 & 1 & 143 & z & 663 & 休 & 0 & x & 137 & 你 & 4 \\
\hline & ス & 7 & 休 & 1 & ス & 31 & 休 & 0 & 2 & 86 & 休 & 5 \\
\hline
\end{tabular}

略記罥：ス(スイカ)、キ(キュウリ)，レ(レタス)、ラ(ラッカセイ)，ト(トウモロコシ)，休(休閉)

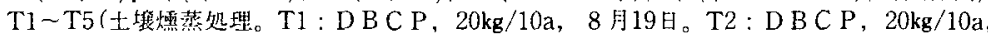
3 月 2 日。T3: D-D, 30l/10a, 8 月21日。T4:D-D, 30l/10a, 4 月19日。T5:D-D, $30 l$ $10 \mathrm{a}, 8$ 月30日)。 $\mathrm{a}:$ 地下 $5 \sim 15 \mathrm{~cm}$ の耕土の乾士 $30 \mathrm{~g}$ 当り㭇出出数。

b : 地下 $0 \sim 30 \mathrm{~cm} の 10 \mathrm{~cm}$ 毎の層位別乾土 $30 \mathrm{~g}$ 当り娭出平均虫数。c：ウィルス病発生のため生青途 中植えかえる。 $\mathrm{d}$ ：線虫寄生による生育幄延，停止株多発生。e：スイカ及びュウがオ版任粈培。

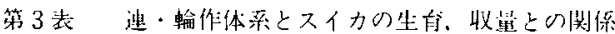

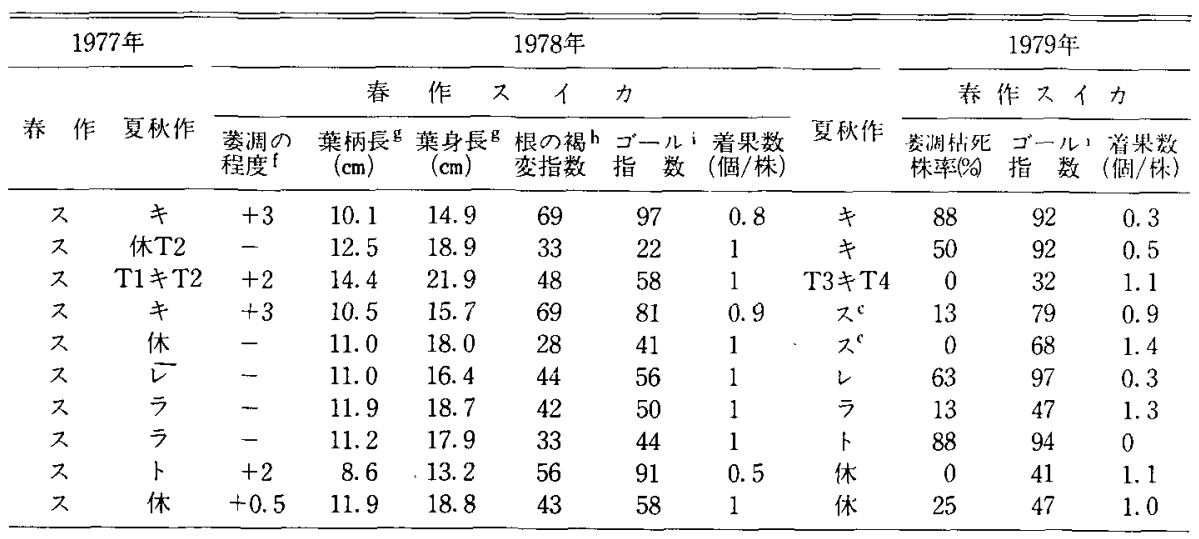

略記号およじcの注は第2表に同じ。f:-(健全) + +4(全株萎调)。g:10 15節の葉について测定。 $\mathrm{h}:$ 恨の 褐変度, 0 (健全)，1(褐変微)，2(恨の全長の1/3褐変)，3(2/3)，4(3/3)，にわ什て調查し次式で求めた。

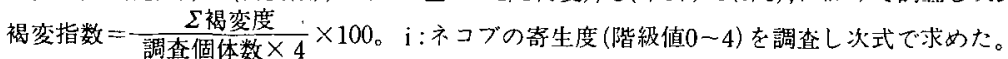
ゴール指数 $=\frac{\sum \text { 寄生度 }}{\text { 調查個体数 } \times 4} \times 100$ 。

抑制していない。従って，これら作付体系は本線虫の䓫 生・増殖に好適条件を提供したものと推察される。一方 スイカーラッカセイ，スイカ一休閑体系はスイ力作によ る密度復元が楒められるものの, 他の作付体系に比較し 机線虫の密度は低く経過した。

なお、ここで注目すべき点はトウモロコシ（品種：ア ソ在来, 交 3 号) 划培でサッマイモネコブセンチュウの 密度増加がみられ, 增殖を確認したことである。従来, トりモロコシは病害の被害回避, 地功維持, ほ場珮生の 面からも，輪作作物あるいは净化作物として導入するこ とを推冾されたものであり，ネコブセンチュウ類に対し
ても, 密度抑制の効果や，少なくとも增加が見られない と報告されている ${ }^{1,2,3)}$ 。従って，当初はトウモロコシに 本線虫の抑制効果を期待して試験をしたが,結果は逆に， 線虫の著しい增殖をみた。後述するように，トウモロコ シ後作物のスイカで，萎调症を誘発させたと判断される ほどの線虫密度の顕著な堌加であった。

なお，別の試験 ${ }^{4)}$ で卜ウモロコシ39品種系統を供侙し たサッマイモネコブセンチュウ抵抗性検定でも，線虫密 度減少効果のある品種は兒出し得なかった。輸作作物之 してトウモロコシを導入するにあたっては慎重な検討が 必要亡思和狆。 
2. スイカの生育, 収量及び萎调定

1977年夏秋作にキュウリ，トゥモロコシを栽培した後 の1978年春作スイカは草勢が弱く，着果は遅く不揃いで 着果数も少なく，また，果実の肥大も遅い㑯向にあった (第 3 表)。さらには定植後 2 力月頃から缕凋症状が徐々 に発生し，ついには枮死する株も認められた。このよう な萎调を呈したスイカの符は細く，葉柄，葉身長が短く 明らかに生育は少っていた。

根の調查ではゴール指数，根の䶂変指数ともに高く， さらに褐変部位办らはそう菌類, Rhizoctonia 属菌が分 離された (熊本農陚)。また, 節間長, 接木部分（台木, 穂木）の直径, 導管数, 導管の闒々く程度及び根数, 根 の太さ等を調査したが，萎调程度と一定の頃向は認めら れなかった。さらに土壤中の硝酸態窒素， $\mathrm{pH}$ ，水による 塩類抽出液の電気伝導度にも差異は認められなかった。

キュウリ，トウモロコシ，レタス後作の1979㤰春作ス イカでも, 定植前線虫密度から推定して, 萎调症の発生 汃予想さ机，その後奏際に菱凋枯死株分多発生して低収 となった。ラッカセイ区、休䦥区の後作スイカでは前年 同様に资凋枯死株の発生は㧕制された。

以上の試駼結果加判断して，スイ力萎调症の発生に はサツマイモネコブセンチュウが大きく関与していると 推測できる。また，現地における調査結果でも同様な傾 向を認めた。

一方，根の裀変部位加々う菌類，Rhizoctonia 属菌 が分離されたが，第 1 図に示すようにスイカ根のゴール と，これら病菌類によると思われる襱変との間に高い正 の相関関係が認められた。また，ゴール指数及び褐変指 数之萎凋枯死，着果数，いい換えれば生育，収量之の関

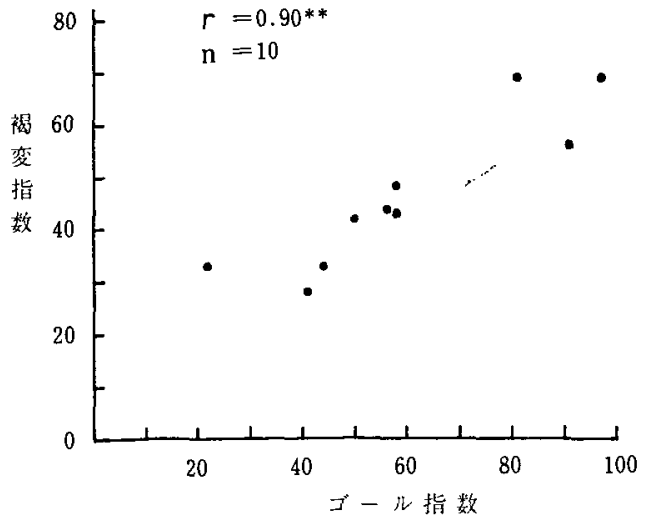

第 1 図 スイカ根のゴールと褐变との関係 (1978年)
係も同様に関連していると推定される結果から(第 3 表), 線虫之併せてそう菌類，Rhizoctonia 属菌もスイ力萎凋 症に対し，無視できない発生要因と推察される。しかし ながら，そう菌類，Rhizoctonia 属菌がどのようにスイ 力菱调定に関与しているかについては，さらに検討する 必要があり，現時点では，本淀の発生原内はサッマイモ ネコブセンチュウが大゙きな德因と考えられる。

な抢，分離されたこれら菌類と萎调症との関係につい ては，現在も試験を継絸し検討中でありままたその他の 洘元られる要因についても解析を進めていることを附記 する。

これまでの試験結果から，施設畑にお汗る野菜類運作， 特にウリ類連作及びトウモロコシ作はスイカ萎凋症等の 生育障害を招き易いことが判明し，逆にラッカセイ導入， あるいは休閑ではこれらの障害が抑制されたことから輸 作の重要性が示睃された。今後さらに産地に適合した輪 作作物を探索し，その体系化之效率的な生育障㕩回避技 術の確立をはかる必要がある。

摘要

スイカを基幹とする地設畑の生育障整要因究明と対策 を目的とし，サッマイモネコブセンチュウがスイカの生 逳，収量に及济す影響を検詂するため，各種連・輪作試 験を奏施した。

1. スイカキュウリ，レタス，トウモロコシ栽堷は 本線虫の密度増加を著しく助長し，特にキュウリ，トウ モロコシでは顕著であった。

2. トゥモロコシは従来の知見とは逆に本線虫を增殖 させた。

3. ラッカセイ溨培及び休䦥は線虫密度を抑制した。

4. スイカーキェウリ及びトウモロコシ導入体系は, 特に線虫密度を高內るとともにスイカ萎调症を誘発した。 5. スイカーラッカセイ，スイカー休閑体系は線虫密度 をスイカの被害水準以下に抑制した。

6. スイカ萎调症の発生原因はサツマイモネコブセン チュウによる根系障害が大きな要因と考元られる。

\section{引用文献}

1）後滕昭（1976）九病出研会報 $22: 123-126.2$ 2) 妱 野俊郎・野村个・後藤昭・大庭宾雄・近藤信 (1976) \% 州農業研究 $38: 78-79 . \quad 3)$ 古賀成司・古闌孝彦

(1981) 九州農業研究 43 (投稿予定). 4) 宮畸県 総農試（1965）昭和40年度土埩病害虫防除改善斌験成績 言（線虫関係）,11-15（とう写）。

(1980年 5 月16日 受領) 